\title{
Techno-economic Feasibility Analysis of an Off-grid Hybrid Renewable Energy System for Rural Electrification
}

\author{
Jamil Ahmed ${ }^{1}$, Khanji Harijan², Pervez Hameed Shaikh ${ }^{3}$, Amjad Ali Lashari ${ }^{3, *}$ \\ ${ }^{1}$ Department of Energy Systems Engineering, Mehran University of Engineering and Technology, Jamshoro, Sindh, Pakistan \\ ${ }^{2}$ Department of Mechanical Engineering, Mehran University of Engineering and Technology, Jamshoro, Sindh, Pakistan \\ ${ }^{3}$ Department of Electrical Engineering, Mehran University of Engineering and Technology, Jamshoro, Sindh, Pakistan
}

Email address:

jamiltapi@gmail.com (J. Ahmed), Khanji.harijan@faculty.muet.edu.pk (K. Harijan), pervez.hameed@faculty.muet.edu.pk (P. H. Shaikh), amjadalilashari158@gmail.com(A. A. Lashari)

${ }^{*}$ Corresponding author

\section{To cite this article:}

Jamil Ahmed, Khanji Harijan, Pervez Hameed Shaikh, Amjad Ali Lashari. Techno-economic Feasibility Analysis of an Off-grid Hybrid Renewable Energy System for Rural Electrification. Journal of Electrical and Electronic Engineering. Vol. 9, No. 1, 2021 , pp. 7-15.

doi: $10.11648 /$ j.jeee.20210901.12

Received: December 16, 2020; Accepted: December 31, 2020; Published: January 12, 2021

\begin{abstract}
The demand for electricity in remote rural areas is a major obstacle to their development. The extension of the grid network to remote rural areas has been identified as a difficult topography for complex constructions and enormous investments. The development of off-grid renewable energy generation technologies offers the opportunity for tackling these challenges. This study provides a techno-economic feasibility analysis of an off-grid hybrid renewable energy system for a rural village of district Kech, Balochistan, Pakistan. The proposed hybrid system integrates the different combinations of the wind turbine, solar PV modules, and battery backups to meet the required electric load demand. The hybrid system is modeled and optimized through a powerful simulation software Hybrid Optimized Model for Electric Renewable (HOMER-Pro). The optimized configuration of the hybrid system consists of wind turbines $(12 \mathrm{~kW})$, solar PV $(103 \mathrm{~kW}), 224$ lead-acid batteries (72.4Ah each), and $29.1 \mathrm{~kW}$ converters. The simulation results show that the proposed system can meet the power requirements of $197.74 \mathrm{kWh} /$ day primary demand load with $27.87 \mathrm{~kW}$ peak load. This system configuration has the Net Present Cost (NPC) of $\$ 127,345$ and Cost of Energy (COE) of $0.137 \$ / \mathrm{kWh}$ with a $100 \%$ renewable fraction. Furthermore, the results of the present study are compared with the literature and have resulted in a cost-effective hybrid renewable energy system with a low COE.
\end{abstract}

Keywords: Techno-economic, Feasibility, COE, Hybrid, NPC

\section{Introduction}

Energy is the main pillar of the social and economic stability of a country. Due to modern living standards, industrialization, and population growth, the current energy demand is gradually increasing day by day [1]. According to research done by United Nations Environment Program (UNEP), states that around 2 billion of the population globally do not have access to grid electricity, the majority of them live in rural remote areas of developed and underdeveloping countries. The major worldwide challenge for these countries is to provide cost-effective and reliable energy services to these rural areas. Electricity has been found as a key source for human sustainable development. Installation and supply of grid electricity are financially impracticable or practically not feasible for such specific sparsely populated remote areas [2]. Although, people of these rural areas have several electricity interruptions, and most of them still have no access to electricity. The electrification progress in the rural sector as compared with urban areas is very low. Among the total population having electricity, $80.4 \%$ are from urban areas and $18.7 \%$ are from the remote rural areas [3]. The electrification of remote areas is a vital need for developing these areas to achieve economic growth, eradicate poverty, and improve livelihoods. Mostly conventional methods are used to supply electricity to these areas such as utility grid extension and diesel generators. 
Extension of the grid to every rural community is sometimes uneconomical and practically not feasible due to irregular topography, geographical inaccessibility, and immense investments [4]. Using diesel generators as an alternative source for electrifying remote areas is not attractive due to the rapid exhaustion of fossil fuels, high transportation prices, and environmental pollutions [5].

In Pakistan, around 62 percent of the population lives in remote areas, and a majority of them still do not have access to electricity from the grid. Being a developing state, Pakistan is facing the worst environmental and social challenges. The growing population throughout the country is increasing electricity demand. The current energy supply is around $17000 \mathrm{MW}$ whereas the energy demand is approximately $25000 \mathrm{MW}$, producing a gap in supplydemand around $8000 \mathrm{MW}$ [6]. That results in a shortfall of electricity around 16-18 hours in rural areas and 12-14 hours in urban areas [7]. The condition in Balochistan is even worse as the electricity is unavailable for several days. Even though being rich in energy-producing sources such as coal, natural gas, oil, and other renewable energies, Balochistan has been denied enough electricity access. Several studies have been defined that around 85 percent of the province population lives in remote areas and about 90 percent of the rural villages are not electrified [8]. These rural villages are dispersed over distant and large areas. Linking such areas to the national grid is costly and uneconomic. The demand for electricity for houses in rural villages is very low [9]. Therefore, the energy sectors are now shifting towards renewable energy sources for electricity generations in a more efficient, eco-friendly, and cost-effective way. Such renewable sources deliver feasible options for the electrification of rural areas that have enough renewable sources such as hydro, wind, and solar, etc.[10]. In recent days, hybrid renewable energy sources (HRES) have developed to be a favorable technology for electrifying those areas [11]. The renewable energy sources are the most abundant in nature, environmentally friendly, and free available. Among different renewable energy resources, the combination of solar and wind energy due to their balancing nature and negligible carbon emissions delivers reliable and economical options to form a hybrid renewable energy system for rural electrification [12].

Rajbongshi et al. [13] studied PV/biomass/diesel with grid connection for electrification of rural areas considering the peak load demand. The HOMER-Pro software was used for optimization and found that as the load demand increases or the peak load decreases, the COE will be reduced. Therefore, the load management in a proper way for the reduction of peak load and improving the load factor is necessary to reduce the COE of electricity, especially, for off-grid models. Furthermore, the study concludes that extension of the utility grid within the breakeven distance is feasible and beyond the breakeven distance hybrid off-grid is preferred to a costeffective solution for electrifying such rural areas. Munuswamy et al. [14] performed a comparative study to analyze the grid-based electricity for the health center in a remote area with fuel cell electricity production systems with the help of simulation software HOMER. The study determined that the electric supply from the grid is more economical than the off-grid system if the grid system is far beyond $44 \mathrm{~km}$. The work was implemented for an entity with low electricity consumption. Similarly, Singh et al. [15] investigated the economic analysis for biomass, fuel cell, and biomass-based hybrid energy system for Bhopal energy centers using HOMER software. The work has been executed for a primary consumption of load $101 \mathrm{kWh} /$ day. The cost comparative analysis was done with the variation of biomass quantity with ignoring load variation and hydrogen fuel for fuel cells. Hafez and Bhattacharya [16] considered the offgrid hybrid energy system which was based on solar, hydro, diesel, and wind sources for the peak load of $1183 \mathrm{~kW}$ and the base load of the village community. The study was performed by assuming idealistic hypotheses for the systems. Valente and De Almeida [17] performed a feasibility analysis of a hybrid solar PV with a diesel generator system for a rural community of 100 households. The proposed system was supposed to be more economical than a diesel-based generator system which decreases the cost of fuel oil consumption. Similarly, Lau et al. [18] investigated a cost analysis PV/diesel hybrid energy system for a residential load sector using simulation software HOMER. The system was analyzed and designed for the 40 families with $2 \mathrm{~kW}$ of peak load. The productive electricity use was not considered for this study as the system was overdesigned with two $50 \mathrm{~kW}$ generators and $60 \mathrm{~kW}$ of solar PV as the load demand was 80 kW. Olatomiwa et al. [19] performed several feasibility analyses on electricity production systems using wind, diesel generator, and solar energy systems for several areas of Nigeria using HOMER software for simulation. The study found that hybrid renewable energy configurations with the wind, solar, storage batteries, and diesel generators are most feasible with low greenhouse gas emissions. The proposed study has only focused on the basic demand of the selected rural area without considering the productive energy usage. Sharma et al. [20] investigated an optimized feasibility design for electrification of a rural village with considerable sources biomass, solar PV, diesel, and hydro with a peak load of $55.49 \mathrm{~kW}$. The simulations were performed using HOMER. The results concluded that a system with $16 \mathrm{~kW}$ biomass, 6 $\mathrm{kW}$ biogas generators, $10 \mathrm{~kW}$ diesel generators, and $10 \mathrm{~kW}$ solar PV with battery backup shows a suitable choice for the electrification of the selected area.

From the above literature, it is noted that hybrid renewable energy systems are feasible and cost-effective for rural electrification. The applications of such hybrid systems throughout the country are less conclusive. The selected village Dumb Kalat Balagatar, Balochistan has no excess of electricity despite having sufficient renewable energy sources. This study aims to define the feasibility analysis of PV/wind hybrid energy system with storage batteries as backups for local electricity production to electrify the village. 


\section{Methodology}

The objective of this work is to investigate the prefeasibility of renewable-based energy systems for remote areas of Balochistan, Pakistan. The distributed generation system is linked to the load in a microgrid structure and all the loads are considered as AC load, therefore no high power conversion is needed. For achieving the objective following measures are needed: selecting a suitable region, exploring the available renewable resources of that location, designing the hybrid renewable energy system based on available resources of the selected area.

\subsection{Study Location}

The selected area for this study is Dumb Kalat Balgatar village in Kech district, Balochistan, Pakistan as shown in figure 1. Because of unavailable power supply, the villagers depend on conventional sources for their basic energy need such as indoor lighting, cooking, etc. and there is no method to use other appliances such as TV, fridge, and fans. The area around the village is partially hilly and flat plain with sufficient renewable sources to fulfill the energy demand of the villagers. The detail of the selected village is shown below in Table 1.

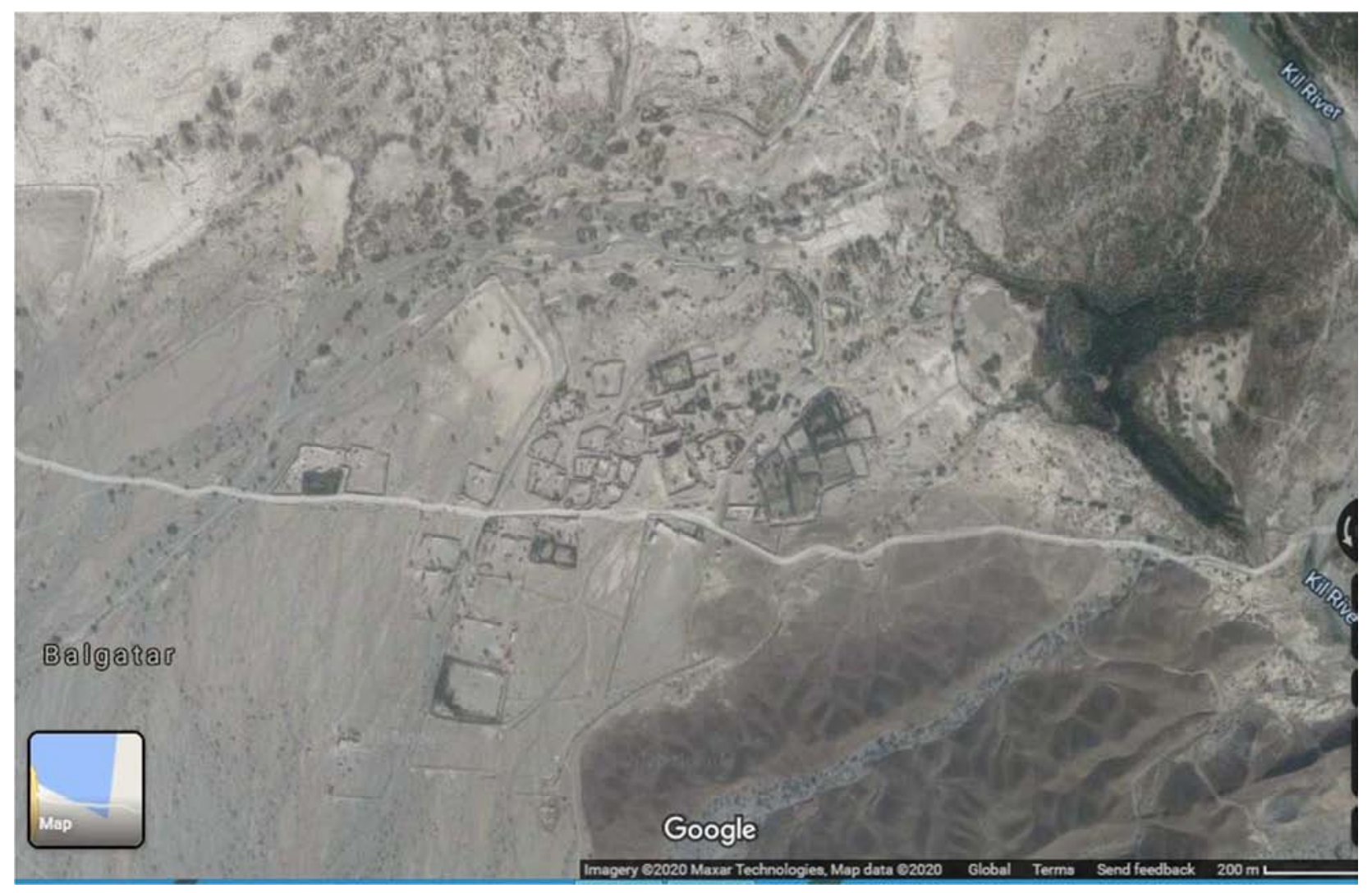

Figure 1. Map of the selected village Dumb Kalat Balgatar, Balochistan.

Table 1. Geographical details of the selected village.

\begin{tabular}{ll}
\hline Name of the Village & Dumb Kalat Balgatar \\
\hline District & Kech \\
Province & Balochistan \\
Country & Pakistan \\
Population & 264 \\
Households & 44 \\
Average family Size & 6 \\
Longitude & $64^{\circ} 2.3 \mathrm{E}$ \\
Latitude & $26^{\circ} 10.01 \mathrm{~N}$ \\
\hline
\end{tabular}

\subsection{Resource Assessment}

For simulation wind and solar energy sources are considered to design a hybrid renewable energy system. Solar energy radiations are almost available throughout the year at the selected village, as in summer the solar radiations are available for a long time about 10 to 12 hours and in winters the radiations are available slightly shorter about 8 to 10 hours. The maximum temperature of the selected location in summer goes to $40-45^{\circ} \mathrm{C}$. The data for the solar radiations are collected from the database of the National Aeronautics and Space Administration (NASA). For the selected region the annual average solar radiations and the clearness index for this work are scales to be $5.71 \mathrm{kWh} / \mathrm{m}^{2} /$ day and 0.634 
respectively. In figure 2 shows the monthly solar radiations that confirm excellent solar potential of site for utilizing the solar energy systems for electrification.

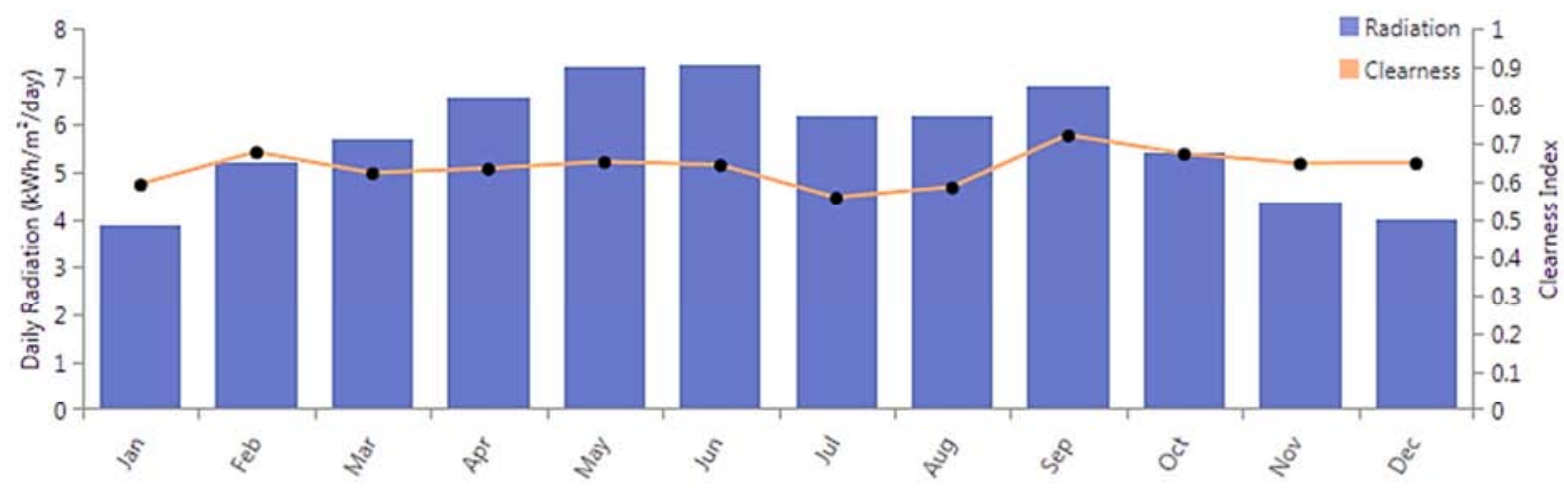

Figure 2. Solar Radiations throughout the year.

The data of average monthly wind speed for the selected village throughout the years is also collected from the National Aeronautics and Space Administration, measured with $50 \mathrm{~m}$ anemometer height. The maximum and minimum wind speed found ranging from $8.77 \mathrm{~m} / \mathrm{s}$ to $5.97 \mathrm{~m} / \mathrm{s}$, with the average of $7.45 \mathrm{~m} / \mathrm{s}$ as shown below in figure 3 .

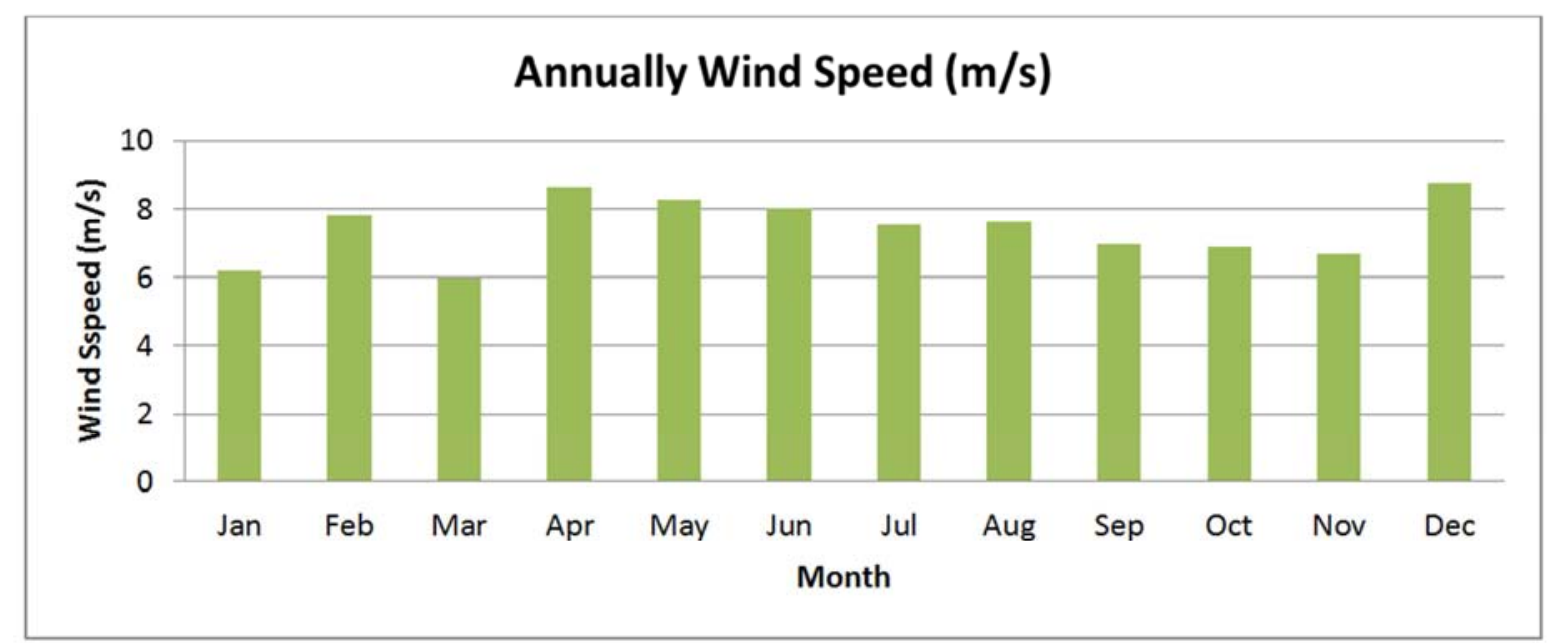

Figure 3. Average wind speed.

\subsection{Modeling Software}

There are numerous modeling software's available for feasibility analysis of energy generation systems, such as HOMER, iHOGA, RETScreen, and Hybrid2 [21]. All of the modeling software has different features such as application areas, analysis methods, or power range applications. In this work Homer pro software is used because this simulation tool is commonly used, easy off-gird modeling. Furthermore, it can estimate the size based on economic viability as well as technical compatibility [22]. Homer pro simulation tool is established by the National Renewable Energy Research Laboratories (NERL) in the USA (United States of America) for renewable energy systems analysis. The modeling tool defines the specifications of the components and also estimates different costs including the system such as life cycle cost, operation, and maintenance cost, net present cost, and the cost of energy. In this work, the system consists of wind turbines, solar PV, battery, and converter of different sizes, homer pro software is used to find out the most feasible system which economically meet the demand load.

\subsection{Electricity Load Assessment}

The load demand of the selected village is sensibly estimated as the current load profile of a similar rural village in the town. Personal decisions of local inhabitants are also considered. The seasonal demand has been estimated according to the area includes winter and summer, with the consideration of utilization time and power of the different appliances holding for a rural household. The residential load demand of the selected village is considered that includes Televisions (TV), radio, fridge and compact fluorescent lamps (CFL), and other primary use appliances for a typical household in rural communities. The detailed load profile of the selected village is shown in the Table. 2 . The village has 44 households with an average of six family members the primary load demand of the village is $197.74 \mathrm{kWh} /$ day having a peak load of $27.84 \mathrm{~kW}$. The impact of a load from two 
different seasons winter and summer are considered.

Table 2. Estimated Load Demand of the Village.

\begin{tabular}{|c|c|c|c|c|c|c|c|}
\hline \multirow{2}{*}{ S. No } & \multirow{2}{*}{ Appliances } & \multirow{2}{*}{$\begin{array}{l}\text { No's in } \\
\text { use }\end{array}$} & \multirow{2}{*}{$\begin{array}{l}\text { Wattage } \\
\text { (W) }\end{array}$} & \multicolumn{2}{|l|}{ Summer } & \multicolumn{2}{|l|}{ Winter } \\
\hline & & & & hrs./day & Wh/day & hrs./day & Wh/day \\
\hline 1 & Fridge/Refrigerator & 1 & 90 & 24 & 2160 & 18 & 1620 \\
\hline 2 & Energy savers bulbs & 3 & 12 & 7 & 252 & 9 & 324 \\
\hline 3 & Ceiling fans & 3 & 36 & 8 & 864 & 0 & 0 \\
\hline 4 & Water pumps & 1 & 500 & 1 & 500 & 1 & 500 \\
\hline 6 & Washing machine & 1 & 500 & 1 & 500 & 1 & 500 \\
\hline 7 & phone charger & 2 & 8 & 3 & 48 & 3 & 48 \\
\hline 8 & Radio & 1 & 10 & 2 & 20 & 2 & 20 \\
\hline \multirow[t]{3}{*}{9} & TV & 1 & 50 & 3 & 150 & 3 & 150 \\
\hline & Total load for 01 household & & & & 4494 & & 3162 \\
\hline & Total load for 44 households & & & & 197736 & & 139128 \\
\hline
\end{tabular}

\section{Model Details}

For techno-economic analyses and designing of the system needs technical details and costs of the different components used in the system modeling. Homer pro (version 13.3.3) was used for assessing the system. The components detail and the system model in detail are shown below.

\subsection{Details of the Components}

The key sources of the proposed hybrid system for the selected village are wind and solar energies. For the proposed design model the components used are wind turbines, storage batteries, solar panels, and converter. The cost and technical parameters data of the components are collected from fast literature and market surveys.

\subsubsection{Wind Turbine}

A generic wind turbine is used for the proposed model as the specifications are shown in Table 3. The initial capital and replacement cost of the turbine as taken as $\$ 4000$ and the operating cost of the turbine is $\$ 200 / \mathrm{yr}$. The wind turbines are connected with AC load outputs [23].

Table 3. Wind Turbine Specifications.

\begin{tabular}{lll}
\hline S. No & Wind turbine specification & \\
\hline 1 & Model & Generic $3 \mathrm{~kW}$ \\
2 & Rated capacity $(\mathrm{kW})$ & 3 \\
53 & Hub size $(\mathrm{m})$ & 30 \\
4 & Manufacture & Generic \\
5 & Life time & 25 years \\
\hline
\end{tabular}

\subsubsection{Storage Battery}

To meet the demand load in the evening hours, storage batteries are used as a backup source for the system. The Lead-Acid battery of $1 \mathrm{kWh}$ is selected for the proposed hybrid model; the specifications of the storage system are shown in Table 4. The initial and replacement cost of the battery is selected as $62 \$$ and $\$ 50$ per unit battery, with the O\&M cost of $\$ 6 / y r$, with the lifetime 5 years [24].
Table 4. Storage Battery Specifications.

\begin{tabular}{lll}
\hline S. No & Storage specification & \\
\hline 1 & Model & BAE PVS Block \\
2 & Nominal voltage (v) & 12 \\
3 & Nominal capacity (kWh) & 0.869 \\
4 & Maximum capacity (Ah) & 72.4 \\
5 & Round-trip efficiency (\%) & 85 \\
6 & Maximum charge current (A) & 11.2 \\
7 & Maximum discharge current (A) & 119 \\
\hline
\end{tabular}

\subsubsection{Solar PV Panels}

The solar PV system is connected with a DC bus, the initial and replacement cost for a $1 \mathrm{~kW} \mathrm{PV}$ panel is considered as $\$ 350$, with the operating cost is $5 \$ / \mathrm{kW} / \mathrm{yr}$, as the maintenance is very low for PV panels. The de-rating factor is taken as $88 \%$ for each PV panel [25]. The detailed descriptions of the solar PV are shown below in Table 5.

Table 5. Solar Panels Specifications.

\begin{tabular}{lll}
\hline S. No & PV plate specification & \\
\hline 1 & Model & Canadian All-Black CS6K-290MS \\
2 & Panel type & Flat plate \\
3 & Rated capacity $(\mathrm{kW})$ & 1 \\
4 & Manufacture & Canadian Solar \\
5 & Life time (years) & 25 \\
\hline
\end{tabular}

\subsubsection{Converter}

Table 6. Converter Specifications.

\begin{tabular}{lll}
\hline S.No & Converter specification & \\
\hline 1 & Maximum power capacity & $30 \mathrm{~kW}$ \\
2 & Maximum Current & $39 \mathrm{~A}$ \\
2 & Rated Voltage & $480 \mathrm{VAC}$ to $400 \mathrm{VAC}$ \\
3 & Frequency & $60 \mathrm{~Hz}$ or $50 \mathrm{~Hz}$ \\
4 & Efficiency & $96 \%$ \\
5 & Peak efficiency & $97 \%$ \\
6 & Life Time & $15 \mathrm{yrs}$ \\
\hline
\end{tabular}

The converter of ideal powers 30B3-4DF model is used for AC-DC conversion. The initial and replacement cost of the converter is taken as $104 \$ / \mathrm{kW}$. The lifetime of the converter 
is considered as 15 years. The efficiency of the inverter is

shown in Table 6.

taken as $96 \%$ [26]. A detailed description of the inverter is

Table 7. Detail Cost Summary of the Components.

\begin{tabular}{lllll}
\hline S.No & Components & Initial Cost (\$) & Replacement Cost(\$) & Operating cost (\$) \\
\hline 1 & Wind turbine & 4000.00 & 4000.00 & 200.00 \\
2 & Solar PV panels & 350.00 & 350.00 & 5.00 \\
3 & System Converter & 104.00 & 104.00 & 0.00 \\
4 & Storage Battery & 62.00 & 50.00 & 6.00 \\
\hline
\end{tabular}

\subsection{Hybrid Model Configuration}

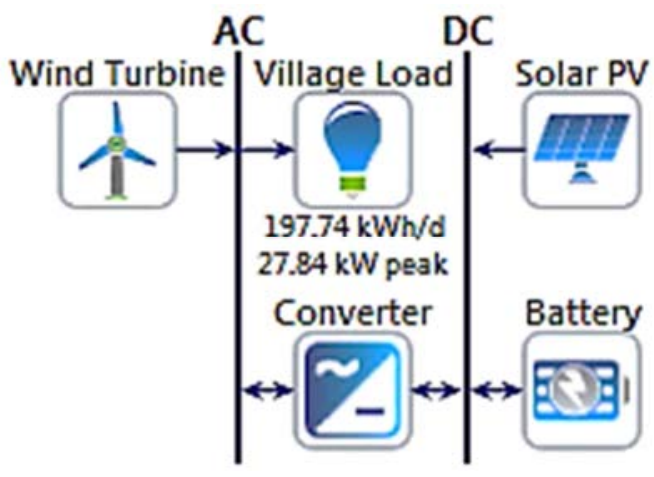

Figure 4. System Model

The proposed hybrid off-grid renewable energy system as shown in figure 4 , is the combination of wind energy, solar PV arrays, converter, storage batteries, and other necessary accessories. The solar PV, converter, and storage battery systems are connected to the DC bus and the wind turbine is connected to the AC load. Both the wind turbine and solar PV works to meet the load demand. When the power output from these two energy sources is well enough for supply load then the storage batteries will be charged from the excess electricity generated from these energy sources. When the power produced from the wind turbine and solar PV arrays are not enough for the demand load to supply in cases such as low wind speed or solar radiations, the charged batteries work to compensate for the energy shortfall. At evening hours, the power generation from PV arrays becomes zero, therefore the batteries or wind energy will meet the demand load. To find out the most feasible hybrid energy combination system in terms of economic and technical aspects the simulation software homer pro is used for simulations and optimization analysis. The model defined the results according to their initial cots, NPC, COE, Capacity shortage, dispatch types, and renewable energy penetration and fraction.

\section{Results and Discussions}

Different configurations with different operating systems were simulated by calculating the energy according to the demand and supply of every time step of the year. The optimal configuration meeting the demand with the lowest NPC will be selected as the most feasible system for the project.

\subsection{Optimization Results}

The simulation software HOMER-Pro runs thousands of simulations to get the most feasible and optimum design system, which is the combination of PV-wind-battery systems with different capacities. Software ranks all feasible systems according to the NPC of each combination. The system with the lowest NPC will be ranked first. The optimum hybrid energy system has the lowest NPC as shown in Table 8 below.

Table 8. Optimization Results.

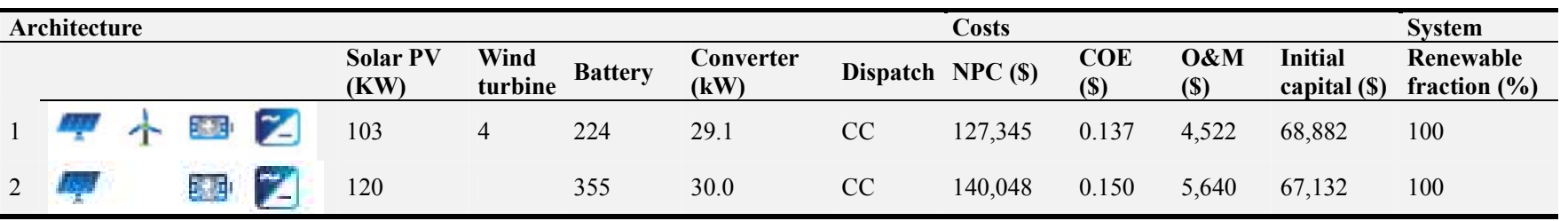

The results show that hybrid (solar PV-wind-battery) system is the most optimized configuration with a combination of $103 \mathrm{~kW}$ of solar PV panels, 4 wind turbines with a rated capacity of $3 \mathrm{~kW}$ each; 224 batteries $(12 \mathrm{v}, 72.4 \mathrm{Ah}$ each) and converter of $29.1 \mathrm{~kW}$, shows the best energy cost of $\$ 0.137$ as compared with the remaining ones.

\subsection{Economic Analysis}

The detailed findings of the economic analysis for the most optimum hybrid energy system are shown in Table 9. The selected scenario has low costs of NPC, COE, and O\&M compared to other systems. Figure 5 shows the cost summary of the components. 


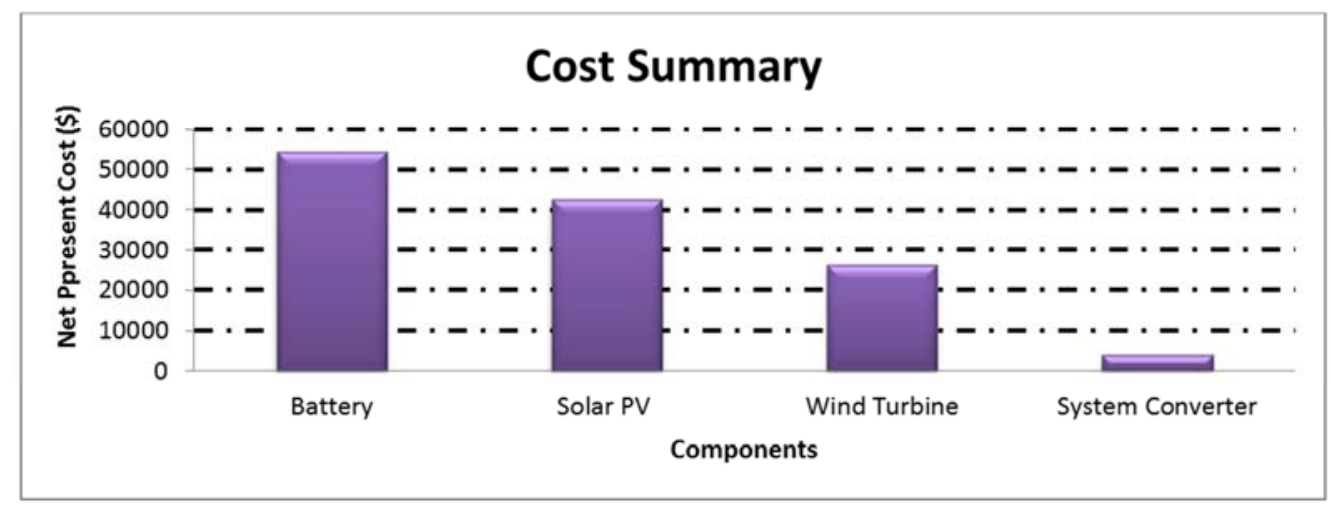

Figure 5. Cost Summary of the Components used in this Study.

The variation of the total cost of the overall system components is shown in figure 5 and Table 9 . From this, it can be observed that the total cost of the system is $\$ 127345.06$ and the cost of the battery, solar PV, wind turbine and system converter are $\$ 54324.84, \$ 42611.4, \$ 26342.01$, and $\$ 4066.81$ respectively. The cost of the battery units is the highest at $42.65 \%$ of the overall cost of the system. In this study, the small size batteries are used due to their availability in the local market.

Table 9. System Cost Summary.

\begin{tabular}{lllll}
\hline Component & Initial Capital (\$) & Replacement (\$) & Operating (\$) & Salvage (\$) \\
\hline BAE PVS Block 12V 70 & 13888.00 & 23062.26 & 17374.58 & 0.00 \\
Canadian Solar All-Black CS6K-290MS & 135968.74 & 0.00 & 6642.66 & 0.00 \\
Generic 3kW & 16000.00 & 0.00 & 10342.01 & 0.00 \\
System Converter & 3024.95 & 1283.41 & 0.00 & 241.55 \\
System & 68881.69 & 24345.67 & 34359.26 & 2611.40 \\
\hline
\end{tabular}

\subsection{Technical Analysis}

Furthermore, the proposed hybrid renewable system shows the larger excess electricity generation with the least cost of energy as compared with other systems.

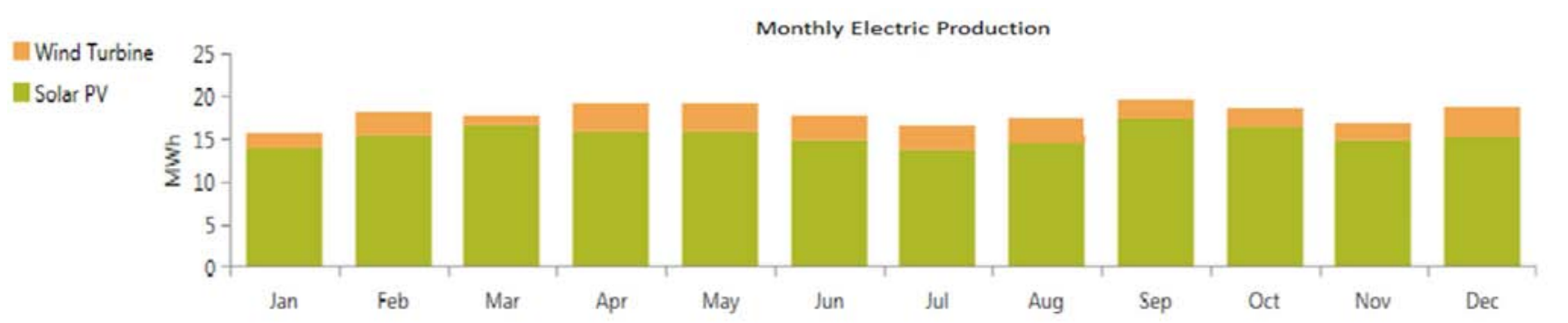

Figure 6. Technical Analysis of the Proposed System.

As from the above figure 6 shows that the electricity production from solar PV is the highest share which contributes $184,145 \mathrm{kWh} / \mathrm{yr}$ which is equivalents to $84.8 \%$ of the total power production; while wind turbine produces $30,497 \mathrm{kWh} / \mathrm{yr}$ ranks the second generator of electric power which is almost equivalent to $14.2 \%$. The total electric power production is $214,642 \mathrm{kWh} / \mathrm{yr}$. The simulation results show that capacity shortage throughout the year is equal to $71.9 \mathrm{kWh}$, with unmet electricity $29.9 \mathrm{kWh}$ and the excess electricity is found to be $63.2 \%$.

\section{Comparing the Study Results with Other Studies}

In Table 10, the results of the present study are compared with the literature in terms of power consumption, COE, NPC, O\&M cost, and electricity production. The highest COE of $0.665 \$ / \mathrm{kWh}$ was achieved by Aboudou and Ganaoui [27], due to less renewable energy sources. Whereas, the lowest COE of $0.137 \$ / \mathrm{kWh}$ is achieved by the current study due to the better optimization technique and high availability of renewable energy sources. Furthermore, the maximum NPC of \$691427 was attained by Li, Liu, and $\mathrm{Li}$ [28], due to high power demand and more components. Last, it is concluded that the available resources in the selected location are suitable for opting for a hybrid (PV/wind/batt) renewable energy system which can be cost-effective and reliable. 
Table 10. Comparison of Present Study with Literature.

\begin{tabular}{|c|c|c|c|c|c|c|c|c|}
\hline Hybrid Systems & Country & $\begin{array}{l}\text { Power Consumption } \\
\text { kWh/day }\end{array}$ & $\begin{array}{l}\text { Peak load } \\
\text { kW }\end{array}$ & $\begin{array}{l}\text { Initial } \\
\text { cost }(\$)\end{array}$ & $\begin{array}{l}\text { COE } \\
(\$)\end{array}$ & $\begin{array}{l}\text { NPC } \\
(\$)\end{array}$ & $\begin{array}{l}\text { O\&M } \\
\text { (\$) }\end{array}$ & $\begin{array}{l}\text { Electricity } \\
\text { Production/yr }\end{array}$ \\
\hline PV/Wind /DG/Batt [28] & China & 564 & 70 & 396008 & 0.285 & 691427 & 22852 & 434448 \\
\hline PV/Wind/Batt [29] & India & 151.650 & 30.5 & 166000 & 0.288 & 228000 & 4944 & 204408 \\
\hline $\mathrm{PV} /$ wind/Batt [3] & Bangladesh & 213 & 30 & 126586 & 0.161 & 224344 & 5007 & 152035 \\
\hline PV/Wind/Diesel/Batt [27] & Comoros & 159 & 9.3 & 133000 & 0.665 & 412009 & 26137 & 129707 \\
\hline PV/Wind/Batt The current Study & Pakistan & 197.74 & 27.84 & 68882 & 0.137 & 127345 & 4522 & 214642 \\
\hline
\end{tabular}

\section{Conclusions}

In this study, the simulation software HOMER-Pro has been used to analyze the feasibility of the wind/PV hybrid system with the backup of storage batteries for the selected rural village in Kech, Balochistan. The daily average load of the village is $197.74 \mathrm{kWh} /$ day with a peak load of $27.84 \mathrm{~kW}$. The optimal hybrid configuration system for the selected region is based on the optimum sizes and the components with the superlative operational techniques that provide an economical, reliable, and efficient system. The simulation results of the study found that the proposed PV-wind hybrid system can produce sufficient power for the electrification of the selected village. The optimized system has been based on 4 wind turbines, rated capacity of $3 \mathrm{~kW}$ each, $103 \mathrm{~kW}$ of PV panels, storage batteries (224 Quantities, 72.4Ah, and 12V), and $29.1 \mathrm{~kW}$ of system converter. The average annual wind speed and the solar radiation of the selected region are approximately $7.45 \mathrm{~m} / \mathrm{s}$ and $5.71 \mathrm{kWh} / \mathrm{m}^{2} /$ day respectively. The COE of this suggested hybrid system has been found as $0.137 \$ / \mathrm{kWh}$. The sensitivity analysis of the parameters demonstrated that this design is the only optimized system under given varieties of various parameters. The application of the designed hybrid system is to facilitate the people living in rural areas with their low monthly income. By enhancing the component's quantity and system capacity the system can be used for educational as well as hospital purposes other than the domestic load. The system performance will be durable and lifelong, the payback period can be achieved in a short period of time and it can also improve the country's economy by supplying electricity in an easy way.

\section{Acknowledgements}

The authors are thankful to the HEC (Higher Education Commission) of Pakistan for project funding under National Program for Universities (NRPU), under Grant NO.6868/Sindh/NRPU/R\&D/HEC 2016 to carry out this study research. The authors would also like to acknowledge MUET (Mehran University of Engineering and Technology) Jamshoro for providing technical support in accomplishing research tasks.

\section{References}

[1] P. E. Yearbook, "Hydrocarbon Development Institute of Pakistan," Ministry of Petroleum and Natural Resources, Government of Pakistan, 2015. [Online]. Available: https://www.hdip.com.pk/. [Accessed: 11-Oct-2020].
[2] J. Kumari, P. Subathra, J. Edwin Moses, and D. Shruthi, "Economic analysis of hybrid energy system for rural electrification using homer," Proc. IEEE Int. Conf. Innov. Electr. Electron. Instrum. Media Technol. ICIEEIMT 2017, vol. 2017-Janua, no. November, pp. 151-156, $2017 .$.

[3] H. S. Das, A. Dey, T. C. Wei, and A. H. M. Yatim, "Feasibility analysis of standalone PV/wind/battery hybrid energy system for rural Bangladesh,” Int. J. Renew. Energy Res., vol. 6, no. 2, pp. 402-412, 2016.

[4] A. Haghighat Mamaghani, S. A. Avella Escandon, B. Najafi, A. Shirazi, and F. Rinaldi, "Techno-economic feasibility of photovoltaic, wind, diesel and hybrid electrification systems for off-grid rural electrification in Colombia," Renew. Energy, vol. 97, pp. 293-305, 2016.

[5] O. D. T. Odou, R. Bhandari, and R. Adamou, "Hybrid off-grid renewable power system for sustainable rural electrification in Benin,” Renew. Energy, vol. 145, pp. 1266-1279, 2020.

[6] A. Raheem et al., "Renewable energy deployment to combat energy crisis in Pakistan," Energy. Sustain. Soc., vol. 6, no. 1, 2016.

[7] N. H. Mirjat, M. A. Uqaili, K. Harijan, G. Das Valasai, F. Shaikh, and M. Waris, "A review of energy and power planning and policies of Pakistan," Renewable and Sustainable Energy Reviews, vol. 79. pp. 110-127, 2017.

[8] Enclude and Foresight Research, Electriity Access in Pakistan Summary Slides, no. March. 2016.

[9] A. W. Bhutto, A. A. Bazmi, and G. Zahedi, "Greener energy: Issues and challenges for Pakistan-Solar energy prospective," Renew. Sustain. Energy Rev., vol. 16, no. 5, pp. 2762-2780, 2012.

[10] J. Senthil kumar, S. Charles Raja, D. Srinivasan, and P. Venkatesh, "Hybrid renewable energy-based distribution system for seasonal load variations," 2018.

[11] R. K. Rajkumar, V. K. Ramachandaramurthy, B. L. Yong, and D. B. Chia, "Techno-economical optimization of hybrid pv/wind/battery system using Neuro-Fuzzy," Energy, vol. 36, no. 8 , pp. 5148-5153, 2011.

[12] M. A. M. Ramli, A. Hiendro, and Y. A. Al-Turki, "Technoeconomic energy analysis of wind/solar hybrid system: Case study for western coastal area of Saudi Arabia," Renew. Energy, vol. 91, pp. 374-385, 2016.

[13] R. Rajbongshi, D. Borgohain, and S. Mahapatra, "Optimization of PV-biomass-diesel and grid base hybrid energy systems for rural electrification by using HOMER," Energy, vol. 126, pp. 461-474, 2017.

[14] S. Munuswamy, K. Nakamura, and A. Katta, "Comparing the cost of electricity sourced from a fuel cell-based renewable energy system and the national grid to electrify a rural health centre in India: A case study," Renew. Energy, vol. 36, no. 11, pp. 2978-2983, 2011. 
[15] A. Singh, P. Baredar, and B. Gupta, "Computational Simulation \& Optimization of a Solar, Fuel Cell and Biomass Hybrid Energy System Using HOMER Pro Software," Procedia Eng., vol. 127, pp. 743-750, 2015.

[16] O. Hafez and K. Bhattacharya, "Optimal planning and design of a renewable energy based supply system for microgrids," Renew. Energy, vol. 45, pp. 7-15, 2012.

[17] L. C. G. Valente and S. C. A. De Almeida, "Economic analysis of a diesel/photovoltaic hybrid system for decentralized power generation in northern Brazil," Energy, vol. 23, no. 4, pp. 317-323, 1998.

[18] K. Y. Lau, M. F. M. Yousof, S. N. M. Arshad, M. Anwari, and A. H. M. Yatim, "Performance analysis of hybrid photovoltaic/diesel energy system under Malaysian conditions," Energy, vol. 35, no. 8, pp. 3245-3255, 2010.

[19] L. Olatomiwa, S. Mekhilef, A. S. N. Huda, and O. S. Ohunakin, "Economic evaluation of hybrid energy systems for rural electrification in six geo-political zones of Nigeria," Renew. Energy, vol. 83, pp. 435-446, 2015.

[20] A. Bhatt, M. P. Sharma, and R. P. Saini, "Feasibility and sensitivity analysis of an off-grid micro hydro-photovoltaicbiomass and biogas-diesel-battery hybrid energy system for a remote area in Uttarakhand state, India," Renew. Sustain. Energy Rev., vol. 61, pp. 53-69, 2016.

[21] S. Sinha and S. S. Chandel, "Review of software tools for hybrid renewable energy systems," Renew. Sustain. Energy Rev., vol. 32, pp. 192-205, 2014.

[22] A. M. Abdilahi, A. H. Mohd Yatim, M. W. Mustafa, O. T. Khalaf, A. F. Shumran, and F. Mohamed Nor, "Feasibility study of renewable energy-based microgrid system in
Somaliland's urban centers," Renew. Sustain. Energy Rev., vol 40, pp. 1048-1059, Dec. 2014.

[23] “AliBaba," $2020 . \quad$ [Online]. Available: https://www.alibaba.com/trade/search. [Accessed: 01-Dec2020].

[24] K. S. A. Shaikh.Suhail Ahmed, Mirjat. Nayyar Hussain, Harijan. Khanji, "Analysis of Hybrid Energy System for Rural Areas; A case Study of Village Shafiabad District Sanghar Sindh, Pakistan," in IEEC 2020.

[25] "Pakistani Stores," 2020. [Online]. Available: https://pakistanistores.com/products/Solar-Panels?page=3. [Accessed: 01-Dec-2020].

[26] I. Panhwar, A. R. Sahito, and S. Dursun, "designing off-grid and on-grid renewable energy systems using homer pro software," 2018.

[27] K. M. Aboudou and M. El Ganaoui, "Feasibility study for the production of electricity using a hybrid PV-wind-generator system in a remote area in Comoros," Int. J. Recent., no. February 2018, pp. 22-36, 2017.

[28] J. Li, P. Liu, and Z. Li, "Optimal design and techno-economic analysis of off-grid hybrid renewable energy system for remote rural electrification: A case study of southwest china," Chem. Eng. Trans., vol. 81, pp. 115-120, 2020.

[29] O. Krishan and S. Suhag, "Techno-economic analysis of a hybrid renewable energy system for an energy poor rural community," J. Energy Storage, vol. 23, no. November 2018, pp. 305-319, 2019. 